\title{
The effect of entrepreneurial orientation, market orientation, total quality management and organizational culture on the SMEs performance: $A$ theoretical framework
}

\author{
Gamal Abdualmajed Ali \\ School of Business Management \\ College of Business, University Utara Malaysia, Malaysia \\ Haim Hilman \\ School of Business Management \\ College of Business, University Utara Malaysia, Malaysia \\ Abdullahi Hassan Gorondutse \\ School of Business Management \\ College of Business, University Utara Malaysia, Malaysia
}

\section{Keywords}

Entrepreneurial orientation, market orientation, total quality management, organizational culture, organisational performance.

\begin{abstract}
In the contemporary, Entrepreneurial orientation and Market orientation have become important topics among business academics and practitioners. Since business environment has become more competitive, the need to develop and improve internal resources is now a prerequisite for global survival; entrepreneurial orientation and market orientation are now the crucial falcons that are assisting the firms to achieve such a niche. Despite the importance of MO and EO, researches that link these concepts to SMEs performance are very limited. In this view, through extensive literature view, this study has found a theoretical link that exists between entrepreneurial orientation, market orientation and performance of SMEs and also developed conceptual model for empirical validations. This study serves not only to clarify the relationship between entrepreneurial orientation, market orientation and SMEs performance, it also explains the role which TQM plays as a mediator in this relationship which most studies have neglected. Again, the conceptual model also examines the moderation role of the organizational culture in the relationship between TQM and SMEs performance.
\end{abstract}

Corresponding author: Gamal Abdualmajed Ali

Email address for corresponding author: gamal200941@hotmail.com

First submission received: 20th March 2017

Revised submission received: 12th May 2017

Accepted: 28th May 2017

\section{Introduction}

Over the past decade, the rate of globalization, world-wide competition and changing in needs and desires of customers have increased dramatically (Ebrahimi \& Adeghi, 2013). Moreover, most industrial sectors that operate in the economies of developing countries are witnessing structural and speedy changes unearth economic opportunity for foreign direct investment, unbalanced growth and increased in the uncertainty as a result of environment changes (Chironga, Leke, Lund \& Wamelen, 2011; Goedhuys \& Sleuwaegen, 2010).

For firms to become more efficient and competitive in this regard, many companies are being motivated to change their existing traditional business operations, and as well select and develop best processes to improve products and services to ensure customers satisfaction at competitive costs 
(Zakuan, Yusof \& Shaharoun 2009; Wanjau, Gakure, Peterson \& Kahiri, 2013; Teixeira, Lopes \& Sousa, 2015). Importantly, these changes have given essential challenges and opportunities for companies to take advantage of their capabilities or competence for growth ( $\mathrm{Li}$, Zhao, Tan \& Liu, 2008). These changes have also changed decision making processes and managerial assumptions in numerous entrepreneurial firms, including those decisions taken to achieve opportunities and how customer value can be produced and delivered (Webb, Ireland, Hitt, Kistruck \& Tihanyi, 2011).

To this end, firms have to adopt and implement market orientation (MO), entrepreneurial orientation (EO) and new operation management practices activities, which have been proved to be effective over the years (Sadikoglu \& Zehir 2010; Zakuan et al., 2009).In the same side, many of the authors stressed on the importance of EO, MO and TQM in achieving competitive advantage and enhanced performance of firms (Li et al., 2008; Aziz \& Yassin, 2010; Talib, Rahman \& Qureshi, 2010; Mokhtar \& Yusoff, 2012; Al-Dhaafri, Yusoff \& Al-Swidi, 2013; Calvo-Mora, Ruiz-Moreno, PicónBerjoyo \& Cauzo-Bottala, 2014). Further, previous studies have recognized the organizational culture (OC) as a means of sustainable competitive advantage and a significant driver of best performance (Xenikou \& Simosi, 2006; Rad, 2006; Irani, Beskese\& Love, 2004; Schein, 1984, Wu, Zhang \& Schroeder, 2011).

However, the bulk of extant studies that examined the EO, MO, TQM and business performance focus on large organization, particularly in developed countries (Salaheldin, 2009; Urban, 2010; Mahmoud, 2011; Wales, Gupta \& Mousa, 2011; Raju, Lonial \& Crum, 2011; Mahmud \& Hilmi, 2014). Accordingly, fewer studies are available on EO, MO, TQM in the SMEs (Chao \& Spillane; 2010; Raju et al., 2011; Islam, Khan, Obaidullah \& Alam, 2011; Filser, Eggers, Kraus \& Málovic, 2014; Jabeen \& Mahmood, 2015).

Based on the above premise therefore, it is logical to conclude that previous researchers have not only paid very minimal attention to the EO, MO and TQM in the SMEs; a lot of opportunities still aboundto extend theoretically and empirically the literature on EO, MO, TQM and SMEs performance. Consequently, the specific objective of this article is to avail the research community a conceptual framework that will link EO, MO and SMEs performances, and will equally contribute to the body of knowledge and as well as facilitate the connections between Europe, USA, and other developing and emerging countries such as KSA. Based on the objective of this study, the second part of this paper is literature review on EO, MO, TQM, OC and SMEs performances. The next part of the article unveils the conceptual framework of the study. The framework depicts the relationship between EO, MO, TQM, OC and performances of SMEs. And last part is conclusion and suggestion for future research.

\section{Literature Review}

\subsection{Entrepreneurial Orientation (EO)}

In a general sense, EO refers to firms' the decision-making styles to explore new market opportunities (Lumpkin \& Dess, 1996; Wiklund \& Shepherd, 2003; Walter, Auer \& Ritter, 2006). EO has been a salient topic in entrepreneurship literature and strategic management (Zainol \& Ayadurai, 2011; Miller, 2011; Covin \& Lumpkin, 2011; Covin \& Wales, 2012). In addition, EO is an important factor affecting the marketing, strategy of the organization, leadership, culture of organization as well as growth and profitability of the organizations (Phokha \& Nonsrimuang, 2013; Wijetunge \& Pushpakumari, 2014). In a similar vein, the firm with higher EO will achieve higher organization performance (Ambad \& Wahab, 2013). Therefore, organizations with higher levels of EO perform better than the ones with poor levels of orientation (Keh, Nguyen \& Ng, 2007).

Historically, in the past academic literature presented the EO definition for the first time by Miller (1983) (Covin \& Lumpkin, 2011). It was defined by Miller (1983, p. 770) an entrepreneurial firm "engages in product market innovation, undertakes somewhat risky ventures and is first to come up with 'proactive' innovations, beating competitors to the punch". Morris and Paul (1987) also 
defined EO as the preference of a firm's executive to take calculated risks being innovative, and proactive in their approaches to strategic decision making.

Moreover, three original EO dimensions were developed earlier by Miller (1983) namely, innovativeness, proactiveness, and risk-taking. Subsequently, Miller's three EO dimensions have been converted into measurable scales by Covin and Slevin $(1986 ; 1989)$. Several studies have been applied Miller's model with three dimensions (Wiklund \& Shepherd 2005; Wiklund \& Shepherd, 2011; Kraus, Rigtering, Hughes \& Hosman, 2012; Wang \& Yen, 2012; Ambad \& Wahab, 2013; Filser et al., 2014).

Several researchers examined the association between EO and organization performance focus on large firms, especially, in developed countries (Wales et al., 2011; Urban, 2010). Therefore, there is a sparse of research that examines the influence of EO in the SMEs (Islam et al., 2011). Moreover, Wales et al., (2011) in their empirical research of EO assessment suggest that future research should consider mediation by arguing that there is little understanding of the causal mechanisms of how or why EO affects other variables. Lechner and Gudmundsson (2014) also recommend that there is a need for more research to examine what constructs can mediate between EO and performance.

In addition scholarly works have supported that EO brings about improvement in performance of organization (Wiklund \& Shepherd, 2005; Li et al., 2008; Tajeddini, 2010; Hassim, Nizam, Talib \& Bakar, 2011). Moreover, organizations adopting a high EO expected to have a superior performance better than companies that adopt conservative orientation, where the market share showed improvements and the number of new products, services and processes has shown some growth (Rodrigues \& Raposo, 2011; Rauch, Wiklund, Lumpkin \& Frese, 2009). Hence, firms need to implement EO, because it is considered as an important process that helps a firm to survive, successfully compete and improve its performance (Dimitratos \& Plakoyiannaki, 2003; Teece, 2007).

Moreover, numerous studies have argued that there is a link between EO and TQM (Fernandes, Felgueira, \& Lourenço, 2015; Kim, Kumar \& Kumar, 2012). Besides this, customer satisfaction, open culture and continuous improvement, are common aspects of TQM and innovation (Kaynak, 2003; Sing \& Smith, 2004; Zehir, Müceldili, Zehir \& Ertosun, 2012). Therefore, both technology and human dimensions of TQM practices assist in creating culture and an environment that allows innovation (Hoang, Igel \& Laosirihongthong, 2006). Thus, the following hypotheses should be introduced for further empirical examination.

H1: Entrepreneurial orientation has a significant effect on the organizational performance.

H2: Entrepreneurial orientation has a significant effect on total quality management.

\subsection{Market Orientation (MO)}

MO is regarded as the philosophy of business, through which the firm can recognize and meet customer demands and integrate the concept of marketing through the firm (Aziz \& Omar, 2013). The researchers also strongly support that firms should adopt MO, due to its ability to help firms to achieve sustainable competitive advantage (Zhou, Li, Zhou \& Su, 2008; Kumar, Jones, Venkatesan \& Leone, 2011). Further, MO is regarded as a firm's capability, rare and valuable resources which cannot be copied easily and which emphasize the placement of the customer's needs in the core of organizations' operations and strategy (Polat \& Mutlu, 2012).

At its core, MO related to firm's ability to explore and identify existing and potential customer needs and works to respond to those needs via superior ways (Slater \& Narver, 1995; Day, 1994; Kohli \& Jaworski, 1990). In simple terms, MO approves the necessity of moving closer to the customer (Slater \& Narver, 1998). Within this context, MO includes capability that is possessed by an organization to swiftly act in response to transformation in the market demands by introducing new products and services (Ho, Wu \& Chen, 2010; Adis \& Jubilee, 2010). Therefore, it is logical to assert that MO activities will influence firm's innovativeness (Aziz \& Omar, 2013). 
Notably, the first conceptualizations of MO that was recognized as the main firms' performance determinant was provided by Kohli and Jaworski (1990) and Narver and Slater (1990). Several other studies have however been conducted after the works of Kohli and Jaworski (1990) and Narver and Slater (1990), linking relationship between firm performance and market orientation. Kohli and Jaworski (1990) confirm on the aspects of behaviour MO and defined MO as "organization-wide generation of market intelligence pertaining to current and future customer needs, dissemination of the intelligence across departments, and organization-wide responsiveness to it" (1990, p. 6). In contrast, Narver and Slater (1990) viewed MO as a form of organizational culture. They define MO as the "organizational culture that most effectively and efficiently creates the necessary behaviours for the creation of superior value for buyers and thus, continues superior performance for the business" (1990, p. 21).

In relation to that, Kohli and Jaworski (1990) view MO as being made up of three components; intelligence generation, intelligence dissemination, and organization wide responsiveness. Other scholars such as Narver and Slater (1990) equally identify three dimensions of MO to include competitor orientation, customer orientation, and inter functional coordination. However, both MO approaches have the same goal that means customers remain the main factor of MO thinking and in explaining the behaviour of firms (Vieira, 2010; Shehu \& Mahmood, 2014).

In this regard, a lot of market oriented literature considered that market oriented culture looks to be a very important determinant of improved business performance as it makes customers' needs a priority, while the market oriented firm tries to work better on customer satisfaction, and in this manner, increase the level of firm performance (Li, Wei, \& Liu, 2010: Kumar et al., 2011). Hence, the literature of marketing has considered MO to be a main part of organizational culture (Raju et al., 2011). As a matter of fact, majority of the studies regarding MO have used these three dimensions to measure the MO construct (e.g., Appiah-Adu\& Ranchhod, 1998; Augusto \& Coelho, 2009; Aziz \& Omar, 2013; Julian, Mohamad, Ahmed \& Sefnedi, 2014; Wilson, Perepelkin, Zhang \& Vachon, 2014).

There are numerous studies that reveal a link between $\mathrm{MO}$ and organizational performance in large firms, particularly, in developed countries (Raju et al., 2011; Mahmoud, 2011). Hence, there is a lack of research investigating the impact of MO in the SMEs (Islam et al., 2011). In addition, Herath and Mahmood (2013) recommend the inclusion of the mediator on strategic orientation to the business performance relationship.

Furthermore, studies have supported that MO leads to improve organizational performance (Hassim et al., 2011; Suliyanto \& Rahab, 2012; Aziz \& Yasin, 2010; Mahmoud, 2011; Chen, Tang, Jin, Li \& Paillé, 2015). Related to that, when a market oriented firm identifies customer needs, desires and preferences and strives to satisfy these better than competitor an increase in the level of firm performance will be achieved (Olavarrieta \& Friedmann, 2008). Similarly, to deal with the changing customer demands and preferences, several firms adopt the MO idea, which is considered one of the most important developments in the marketing literatures (Suliyanto \& Rahab, 2012). Therefore, every organization should embrace $\mathrm{MO}$ as a strategy which could be used to build capabilities of the marketing in order to meet customers' needs, satisfaction with the purpose of outperforming the competitors (Liu \& Wang, 2009; Chin, Lo \& Ramayah, 2013).

Additionally, many prior studies have shown there is a relationship between MO and TQM (Zelbst, Green, Abshire \& Sower, 2010; Lam, Lee, Ooi \& Phusavat, 2012). In line with these results, Day (1994) and Mohr-Jackson (1998) confirmed a link between MO and practices of TQM as both are concerned with customer's needs, customer's participation, as well as target to achieve the same final aim customer of satisfaction. Indeed, TQM practices offer a group of tools, which help firms to become market-oriented (Litton, 2001). Furthermore, Day (1994) argues a market oriented firm enhances the process of market and customer sensing. Thus, linking capabilities are essential segments of firm's building, as a result, implementation of TQM helps to enhance capabilities and "at the heart of the TQM is the concept of an organization as an interrelated collection of processes rather 
than an interacting set of functional units". Hence, MO and TQM are complementary (Wang, Chen \& Chen, 2012). Thus, the following effects can be hypothesized:

H3: Market orientation has a significant effect on the organizational performance.

H4: Market orientation has a significant effect on total quality management.

\subsection{Total Quality Management (TQM)}

TQM is a widely recognized management philosophy as a management reference system and as strategic support to achieve sustainable competitive advantage is enabling organizations to obtain superior performance (Calvo-Mora et al., 2014: Abusa \& Gibson, 2013). In fact, TQM allows organizations to develop product quality will improve their competitive position, differentiate their products and business success (Perez \& Gutierrez-Gutierrez, 2013; Lam, Lee, Ooi \& Lin, 2011). Therefore, it is not accidental that Wang et al., (2012) confirms that the TQM ensures continuous process improvement which will help to meet superior customer value and customer needs as well as the alignment of the firm operations and understanding, sharing, and responding to customers through marketing concept. A lot of firms have reached the conclusion that the implementation of TQM can help firms improve competitive abilities as well as provide strategic advantages in the marketplace (Karani \& Bichanga, 2012).

In the extant literature, there are many definitions for TQM as there is no commonly agreed one (Deros, Yusof, Azhari, \& Salleh, 2006).However, several of the existing definitions seem to suggest that all firms' processes are being covered by the TQM (Al-Swidi \& Mahmood, 2012). For instance, TQM was defined as an encompassing approach that works on sustaining an uninterrupted improvement that leads to high quality results of responding, meeting and exceeding the customers' demand and expectation (Flynn, Schroeder \& Sakakibara, 1994). Recently, Kumar, Choisne, Grosbois, and Kumar (2009) equally considered TQM as an inclusive method that combines all the activities of organization to meet and exceed customers' expectations towards achieving overall firm objectives.

Many TQM practices have been identified by many scholars and organisations such as Malcolm Baldrige Award, EFQM (European Foundation for Quality Management), and the Deming Prize criteria. Based on these studies a wide range of empirical investigations have been generated. Black and Porter (1996) identified ten major categories of practices, namely people and customer management, corporate quality culture, quality improvement measurement, supplier partnerships, strategic quality management, external interface management, operation quality planning, teamwork structure, communication of improvement information, and customer satisfaction orientation. Yusof and Aspinwall (2000) analysed the TQM Critical Success Factors (CSFs) in the SMEs such as; human resource development, education and training, leadership, continuous improvement system, measurement and feedback, supplier quality assurance, system and processes, improvement tools and techniques and work environment and culture.

In addition, based on an extensive reviewing of the TQM literature, Sila (2007) identified seven main classification of practices measured in past studies, namely human resource management (HRM), leadership, customer focus, strategic planning, process management, information and analysis, and supplier management. These practices are consistent with the criteria that are used in Malcolm Baldrige National Quality Award (MBNQA), except supplier management. The TQM six practices (i.e., leadership, strategic planning, customer focus, human resource management (HRM), process management and information and analysis) are also seen in past studies (e.g. Prajogo \& Sohal, 2003; Prajogo \& Hong 2008; Tan, 2013; Mahmud \& Hilmi, 2014). Therefore, these criteria will be used in this study.

Furthermore, recent studies showed positive relationship between TQM and organizational performance (Lam et al., 2011; Fening, 2012; Agbola, 2013). However, other studies found negative (Duarte, Brito, Di Serio \& Martins, 2011; Kober, Subraamanniam, \& Watson, 2012; Kannan \& Tan, 2005). These inconsistent results in the literature necessitate a further investigation on the 
relationship between TQM and firm performance, particularly in developing countries where there is a severe lack of relevant studies (Meftah Abusa \& Gibson, 2013).

As mentioned before, previous studies have revealed that there is positive a relationship between EO, MO and TQM (Fernandes et al., 2015; Lam et al., 2012; Lai, 2003). Several empirical studies supports have also been found for a mediating role of TQM. For example, Prajogo and Sohal (2006) investigated the mediating role of TQM practices on the relationship between organization strategy and firm performance. The findings of their study indicated a positive and significant relationship between TQM and differentiation strategy as well as a partial mediation on the relationship between firm performance and differentiation. Moreover, Hung, Lienb, Fangc and McLeand (2010) examined Knowledge management, TQM and innovation performance. They reported that TQM was a mediator between Knowledge management and innovation performance. This discussion leads to the following hypothesis:

H5: Total quality management has a significant influence on the organizational performance.

H6: Total quality management significantly mediates the relationship between Entrepreneurial orientation and organizational performance.

H7: Total quality management significantly mediates the relationship between Market orientation and organizational performance.

\section{4 Organizational Culture (OC)}

In general, OC represents the beliefs, values, and assumptions which members of an organization shared (Sigler \& Pearson, 2000). Specifically, OC is conceptualized as a pattern of shared meanings between members inside an organisation which effect how its employees behave (Denison, 1990). Similarly. Cameron and Quinn (2005) argued that OC is group's values, beliefs, and assumptions which described organizations and their members. Lies the importance of organizational culture as the main instruments which managers can employ to guide the path their organizations (Daft, 2005). Therefore, OC influences the style of work of the organization, affects people's decisions and behaviours and, in impact on firm performance (Wu et al., 2011). This fact has also been supported by Gambi, Boer, Gerolamo, Jørgensen and Carpinetti (2015), and Schein (1984) as they assert that $\mathrm{OC}$ is the main factor to organizational excellence.

In this regard, ignoring the impacts of organizational culture is one of the biggest change problems as it affects the implementation of new initiatives as well as that of dissecting, evaluating and identifying the existing position of the OC is very germane to decide the changes required in order to increase the organizations effectiveness (Cameron \& Quinn, 1999). On other word, OC is considered as one of the unique characteristics that distinguish successful organizations from others (Hilman, Abubakar \& Kaliapan, 2017; Keller \& Richey, 2006). Hence, OC is considered as a source of sustained competitive advantage (Zheng, Yang \& McLean, 2010; Barney, 1986).

Many types of OC have been described in literature. This study will use the model proposed by Cameron and Quinn (2005). The model which is popularly known as competing value has been relatively widely used in prior studies to examine the effect of organizational culture on TQM practices (Zu, Robbins \& Fredendall, 2010; Gimenez-Espin, Jiménez-Jiménez \& Martínez-Costa, 2013; Valmohammadi \& Roshanzamir, 2015).

As it has been indicated earlier, the findings on the relationship between TQM and organizational performance, have been inconclusive (Fening, 2012; Agbola, 2013; Kober, Subraamanniam \& Watson, 2012; Kannan \& Tan, 2005; Samson \& Terziovski, 1999). To resolve the inconsistency of the results, Jabeen, Shehu, Mahmood and Kofarmata (2014) in their study recommended that the moderator variables should be incorporated in the relations between TQM and organizational performance. To respond to this call, this study will use OC to moderate the link between TQM and organizational performance.

In conclusion, several previous studies have found significant relationships of OC with TQM (Haffar, Al-Karaghouli \& Ghoneim, 2013; Zu et al., 2010). In addition, many studies have proofed 
that OC affects the successful implementation of TQM by providing an environment that is conducive to implement TQM as a change strategy towards improving the overall organizational performance (Brah \& Lim, 2006; Powell, 1995). Hence, Rad (2006) argued that the current OC could either promote or inhibit implementation effectiveness TQM.Based on the above discussion, following hypothesis is raised:

H8: Organizational culture significantly moderator the relationship between Total quality management and organizational performance.

\subsection{Organisational Performance}

The issue of performance measurement and management has attracted researchers and scholars interest in the last two decades (Valmohammadi \& Servati, 2011). This is because importance of performance explains how well an organisation is doing (Obiwuru, Okwu, Akpa \& Nwankwere, 2011). According to Madrid-Guijarro, Auken and Lema (2007) performance measure accurately can provide to firms reliable information about what effects performance as well as how firms utilize and organize resources, develop best strategies, meet consumer expectations and compete favourably. Venkatraman and Ramanujam (1986) proposal of business performance model by using both financial and operational measurements to develop a comprehensive assessment of firm performance.

Furthermore, Carton and Hofer (2006) concluded that organizational performance can be described five categories of measures; operational measures (include non-financial variables such as market share and customer satisfaction); accounting measures (relying on financial information); survival measures (long-term organizational performance); market-based measures (ratios of the market value of the organization such as return to shareholders and market value-added); and economic value measures (adjusted accounting measures). On the other hand, (Kaplan \& Norton, 1992, 1996), who introduced a strategic model called the Balanced Scorecard (BSC) offer balanced performance measures for financial and non-financial perspectives in evaluating the organizational performance.

In addition, Kaplan and Norton (1992) went further in arguing that financial management alone is inadequate in assessing an organization's competitive position. As a result, the balanced scorecard strategy retained the financial and added three other non-financial measures - customers, internal process, and learning and growth (Kaplan \& Norton, 1992, 1996). In the same line, several researchers have proposed measurement of performances should consider both financial and nonfinancial measurement test (Gronum, Verreynne \& Kastelle, 2012; Hilman, 2009; Kaplan \& Norton, 2000; MacDougall \& Pike, 2003). Organizational performance in this study, is a subset of organizational effectiveness that covers financial outcomes and non-financial.

Overall, based on the foregoing, the literature reviewed have identified a theoretical gap which need to be fill as demonstrated in the conceptual model. Specifically, it has been established in the literature that all the construct of the paper has proven to have link with organisational performance. First, EO and MO have effect on organisational performance. Some literature reported positive link between the variables while others have a negative result.

Therefore, this mix result in the literature form the very reason for this paper, to further explain the relationship between EO, MO, SMEs performance, the paper introduced TQM as mediating variable. Also, OC was introduced as moderator to further, strengthen the said relationships. 


\section{Conceptual Model}

Based on the reviewed literature and subsequent suggested hypothesis. The following conceptual model was developed to explain the relationship between the variables of the study.

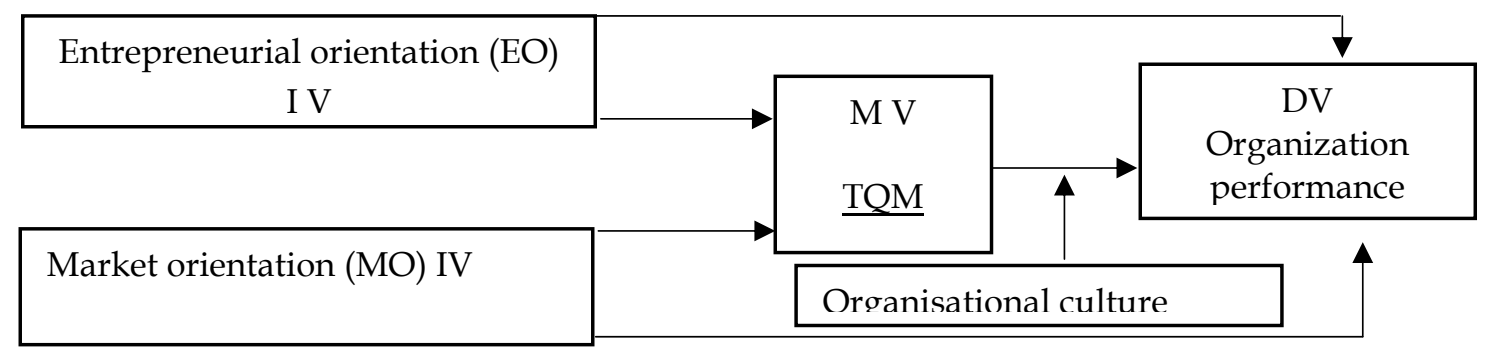

Figure1. Conceptual Model

From the model above a relationship among EO, MO, TQM, OC and SMEs performance. This relationship is underpinned by the resource based view theory which argues that the firm performance is actively impacted by its existing internal resources and capabilities. This assertion comes from the fact that an organization may obtain superior performance than its competitors by effectively making use of its resources. Additionally, extant studies suggest that TQM can mediate the relationship between $\mathrm{EO}, \mathrm{MO}$ and SMEs performance to further explain the relationship in contras of mix finding in the literature. While OC moderates the relationship between TQM and SMEs performance to strengthen the link between the variables of concern.

The model as shown in figure1 aligns with the recommendations of previous scholars (e.g., Raju et al., 2011; Shehu \& Mahmood, 2014; Baron \& Kenney, 1986; Jabeen et al., 2014). TQM as variable can determine the effectiveness of organisation performance. Further, a supportive of OC affects the successful implementation of TQM. Therefore, this paper is unique in the sense that, for the first time it has logically within the context of literature provide a model that will help SMEs have better performance as guided by the previous study and theories.

\section{Conclusion}

This study has provided a conceptual framework that links a relationship between EO, MO, TQM, OC and SMEs performance. Importantly, this study is making an important contribution to the body of knowledge by providing a framework which provides explanation of the influence of the EO, MO on SMEs performance. Moreover, this study is unique as it by elucidating the possibilities of using TQM as a mediator in the relationship between EO, MO and SMEs performance and as well as the role which OC plays as a moderator in the relationship between TQM and SMEs performance. One of the thrusts of this study is that it will raise level of awareness among managers of SMEs to pay more attention to EO, MO, TQM, and OC as it will help them to improve the performance and competitiveness of their organizations.

\section{Limitation and future research}

Nevertheless, just like any other studies, this study has its own limitations. First, since this is a conceptual paper, future research should further verify the claim of this study empirically. Second, the focus of this model is on the SMEs; there is a need to test its veracity in other larger companies and different sectors by future research.

\section{References}

Adis, A. A. A., \& Jublee, E. (2010). Market orientation and new product performance: The mediating role of product advantage. African journal of marketing management, 2(5), 91-100.

Agbola, R. M. (2013). Does Total Quality Management Affect the Performance of Small and Medium Enterprises? A Case of Manufacturing SMEs in Ghana.

Al-Dhaafri, H. S., Yusoff, R. Z. B., \& Al-Swidi, A. K. (2013). The Effect of Total Quality Management, Enterprise Resource Planning and the Entrepreneurial Orientation on the Organizational 
Performance: The Mediating Role of the Organizational Excellence---A Proposed Research Framework. International Journal of Business Administration, 4(1), 66.

Al-Swidi, A. K., \& Mahmood, R. (2012). Total quality management, entrepreneurial orientation and organizational performance: The role of organizational culture. African Journal of Business Management, 6(13), 4717.

Ambad, S. N. A., \& Wahab, K. A. (2013). Entrepreneurial orientation among large firms in Malaysia: Contingent effects of hostile environments. International Journal of Business and Social Science, 4(16).

Appiah-Adu, K., \& Ranchhod, A. (1998). Market orientation and performance in the biotechnology industry: An exploratory empirical analysis. Technology Analysis \& Strategic Management, 10(2), 197-210.

Augusto, M., \& Coelho, F. (2009). Market orientation and new-to-the-world products: Exploring the moderating effects of innovativeness, competitive strength, and environmental forces. Industrial Marketing Management, 38(1), 94-108.

Aziz, N. A., \& Omar, N. A. (2013). Exploring the effect of internet marketing orientation, learning orientation and market orientation on innovativeness and performance: SME (exporters) perspectives. Journal of Business Economics and Management, 14(sup1), S257-S278.

Aziz, N. A., \& Yassin, N. M. (2010). How will market orientation and external environment influence the performance among SMEs in the agro-food sector in Malaysia? International Business Research, 3(3), 154.

Baba, Deros, M., Mohd Yusof, S. R., Azhari, \& Salleh, M. (2006). A benchmarking implementation framework for automotive manufacturing SMEs. Benchmarking: An International Journal, 13(4), 396-430.

Barney, J. B. (1986). Organizational culture: can it be a source of sustained competitive advantage? Academy of management review, 11(3), 656-665.

Baron, R. M., \& Kenny, D. A. (1986). The moderator-mediator variable distinction in social psychological research: Conceptual, strategic, and statistical considerations. Journal of personality and social psychology, 51(6), 1173.

Black, S. A., \& Porter, L. J. (1996). Identification of the Critical Factors of TQM*. Decision sciences, 27(1), 1-21.

Brah, S. A., \& Ying Lim, H. (2006). The effects of technology and TQM on the performance of logistics companies. International Journal of Physical Distribution \& Logistics Management, 36(3), 192-209.

Calvo-Mora, A., Ruiz-Moreno, C., Picón-Berjoyo, A., \& Cauzo-Bottala, L. (2014). Mediation effect of TQM technical factors in excellence management systems. Journal of Business Research, 67(5), 769-774.

Cameron, K. S., \& Quinn, R. E. (2005). Diagnosing and changing organizational culture: Based on the competing values framework. John Wiley \& Sons.

Cameron, K.S. \& Quinn, R.E. (1999). Diagnosing and Changing Organizational Culture: Based on the Competing Values Framework, Addison-Wesley Publishing, Reading, MA.

Carton, RB \& Hofer, CW 2006, Measuring Organizational Performance: Metrics for Entrepreneurship and Strategic Management Research, Edward Elgar, Northampton, MA.

Chao, M. C. H., \& Spillan, J. E. (2010). The journey from market orientation to firm performance: A comparative study of US and Taiwanese SMEs. Management Research Review, 33(5), 472-483.

Chen, Y., Tang, G., Jin, J., Li, J. \& Paillé, P. (2015), "Linking market orientation and environmental performance: the influence of environmental strategy, employee's environmental involvement, and environmental product quality", Journal of Business Ethics, pp. $1-22$.

Chin, C. H., Lo, M. C., \& Ramayah, T. (2013). Market Orientation and Organizational Performance. SAGE Open, 3(4), 2158244013512664. 
Chironga, M., Leke, A., Lund, S., \& van Wamelen, A. (2011). Cracking the next growth market: Africa. Harvard Business Review, 89(5), 117-+.

Covin, J. G., \& Lumpkin, G. T. (2011). Entrepreneurial orientation theory and research: Reflections on a needed construct. Entrepreneurship Theory and Practice, 35(5), 855-872.

Covin, J. G., \& Slevin, D. P. (1986). The development and testing of an organizational-level entrepreneurship scale. Frontiers of entrepreneurship research, 1(1986), 626-639.

Covin, J. G., \& Slevin, D. P. (1989). Strategic management of small firms in hostile and benign environments. Strategic management journal, 10(1), 75-87.

Covin, J. G., \& Wales, W. J. (2012). The measurement of entrepreneurial orientation. Entrepreneurship Theory and Practice, 36(4), 677-702.

Daft, R.L. (2005). The Leadership Experience, 3rd ed., Thomson-Southwestern, Vancouver.

Day, G. S. (1994). The capabilities of market-driven organizations. The Journal of Marketing, 37-52.

Denison, R. D. (1990). Corporate culture and organisational effectiveness. New York: John Wiley \& Sons.

Dimitratos, P., \& Plakoyiannaki, E. (2003). Theoretical foundations of an international entrepreneurial culture. Journal of International entrepreneurship,1(2), 187-215.

Duarte, A. L. D. C. M., Brito, L. A. L., Di Serio, L. C., \& Martins, G. S. (2011). Operational practices and financial performance: an empirical analysis of Brazilian manufacturing companies. BARBrazilian Administration Review, 8(4), 395-411.

Ebrahimi, M., \& Sadeghi, M. (2013). Quality management and performance: An annotated review. International Journal of Production Research, 51(18), 5625-5643.

Fening, F. A. (2012). Impact of quality management practices on the performance and growth of small and medium sized Enterprises (SMEs) in Ghana. International Journal of Business and Social Science, 3(13).

Fernandes, A., Felgueira, T., \& Lourenço, L. (2015, August). Quality, Entrepreneurial Orientation and Performance: An Exploratory Study. In Toulon-Verona Conference" Excellence in Services".

Filser, M., Eggers, F., Kraus, S., \& Málovic, É. (2014). The effect of financial resource availability on entrepreneurial orientation, customer orientation and firm performance in an international context: an empirical analysis from Austria and Hungary. Journal of East European Management Studies, 19(1), 7-30.

Flynn, B. B., Schroeder, R. G., \& Sakakibara, S. (1994). A framework for quality management research and an associated measurement instrument. Journal of Operations management, 11(4), 339-366.

Gambi, L. D. N., Boer, H., Gerolamo, M. C., Jørgensen, F., \& Carpinetti, L. C. R. (2015). The relationship between organizational culture and quality techniques, and its impact on operational performance. International Journal of Operations \& Production Management, 35(10), 1460-1484.

Gimenez-Espin, J. A., Jiménez-Jiménez, D., \& Martínez-Costa, M. (2013). Organizational culture for total quality management. Total Quality Management \& Business Excellence, 24(5-6), 678-692.

Goedhuys, M., \& Sleuwaegen, L. (2010). High-growth entrepreneurial firms in Africa: a quantile regression approach. Small Business Economics, 34(1), 31-51.

Gronum, S., Verreynne, M. L., \& Kastelle, T. (2012). The role of networks in small and medium $\square$ sized enterprise innovation and firm performance. Journal of Small Business Management, 50(2), 257 282.

Haffar, M., Al-Karaghouli, W., \& Ghoneim, A. (2013). The mediating effect of individual readiness for change in the relationship between organisational culture and TQM implementation. Total Quality Management \& Business Excellence, 24(5-6), 693-706.

Hassim, A. A., Asmat-Nizam, A. T., \& Bakar, A. R. A. (2011). The effects of entrepreneurial orientation on firm organisational innovation and market orientation towards firm business performance. International on Sociality ND Economics Development. IPEDR, 10, 280-284. 
Herath, H. M. A., \& Mahmood, R. (2013). Strategic orientation based research model of SME performance for developing countries. Review of Integrative Business and Economics Research, 2(1), 430.

Hilman, H. (2009). Relationship of competitive strategy, strategic flexibility and sourcing strategy on organizational performance. Unpublished PhD Dissertation.

Hilman, H., Abubakar, A., \& Kaliapan, N. (2017). The effect of quality culture on university performance. Journal of Business $\mathcal{E}$ Retail Management Research, 11(4), 25-33.

Ho, S. H., Wu, J. J., \& Chen, Y. (2010). Influence of corporate governance and market orientation on new product preannouncement: evidence from Taiwan's electronics industry. Asia Pacific Management Review, 15(1).

Hung, R. Y. Y., Lien, B. Y. H., Fang, S. C., \& McLean, G. N. (2010). Knowledge as a facilitator for enhancing innovation performance through total quality management. Total Quality Management, 21(4), 425-438.

Irani, Z., Beskese, A., \& Love, P. E. D. (2004). Total quality management and corporate culture: constructs of organisational excellence. Tec novation, 24(8), 643-650.

Islam, M. A., Khan, M. A., Obaidullah, A. Z. M., \& Alam, M. S. (2011). Effect of entrepreneur and firm characteristics on the business success of small and medium enterprises (SMEs) in Bangladesh. International Journal of Business and Management, 6(3), 289.

Ismail Salaheldin, S. (2009). Critical success factors for TQM implementation and their impact on performance of SMEs. International journal of productivity and performance management, 58(3), 215-237.

Jabeen, R. U. B. I. N. A., Shehu, M. S., Mahmood, R. O. S. L. I., \& Kofarmata, B. A. (2014). TQM and Knowledge management impacts on SME performance. International Postgraduate Journal Business Journal,6(2), 23-43.

Jabeen, R., \& Mahmood, R., (2015). The effects of Total Quality Management and Market Orientation on Business Performance of Small and Medium Enterprises in Pakistan. British Journal of Economics, Management \& Trade 5(4): 408-418.

Jinhui Wu, S., Zhang, D., \& Schroeder, R. G. (2011). Customization of quality practices: the impact of quality culture. International Journal of Quality E Reliability Management, 28(3), 263-279.

Julian, C. C., Mohamad, O., Ahmed, Z. U., \& Sefnedi, S. (2014). The market orientation-performance relationship: The empirical link in export ventures. Thunderbird International Business Review, 56(1), 97-110.

Kannan, V. R., \& Tan, K. C. (2005). Just in time, total quality management, and supply chain management: understanding their linkages and impact on business performance. Omega, 33(2), 153-162.

Kaplan, R. S., \& Norton, D. P. (1996). The balanced scorecard: translating strategy into action. Harvard Business Press.

Kaplan, R. S., \& Norton, D. P. (2000). The strategy focused organisation. Harvard Business School Press, Boston.

Kaplan, R.S., \& Norton, D.P. (1992). The balanced scorecard- measures that drive performance. Harvard Business Review, 70 (1), 71-79.

Karani, S. R., \& Bichanga, W. O. (2012). Effects of Total Quality Management implementation on business performance in service institutions: A case of Kenya Wildlife Services. International Journal of Research Studies in Management, 1(1).

Kaynak, H. (2003). The relationship between total quality management practices and their effects on firm performance. Journal of operations management, 21(4), 405-435.

Keh, H. T., Nguyen, T. T. M., \& Ng, H. P. (2007). The effects of entrepreneurial orientation and marketing information on the performance of SMEs. Journal of business venturing, 22(4), 592-611.

Keller, K. L., \& Richey, K. (2006). The importance of corporate brand personality traits to a successful 21st century business. Journal of Brand Management, 14(1), 74-81. 
Kim, D. Y., Kumar, V., \& Kumar, U. (2012). Relationship between quality management practices and innovation. Journal of Operations Management, 30(4), 295-315.

Kober, R., Subraamanniam, T., \& Watson, J. (2012). The impact of total quality management adoption on small and medium enterprises' financial performance. Accounting $\mathcal{E}$ Finance, 52(2), 421-438.

Kohli, A. K., \& Jaworski, B. J. (1990). Market orientation: the construct, research propositions, and managerial implications. The Journal of Marketing, 1-18.

Kraus, S., Rigtering, J. C., Hughes, M., \& Hosman, V. (2012). Entrepreneurial orientation and the business performance of SMEs: a quantitative study from the Netherlands. Review of Managerial Science, 6(2), 161-182.

Kumar, V., Choisne, F., de Grosbois, D., \& Kumar, U. (2009). Impact of TQM on company's performance. International journal of quality \& reliability management, 26(1), 23-37.

Kumar, V., Jones, E., Venkatesan, R., \& Leone, R. P. (2011). Is market orientation a source of sustainable competitive advantage or simply the cost of competing? Journal of marketing, 75(1), 16-30.

Lai, K. H. (2003). Market orientation in quality-oriented organizations and its impact on their performance. International Journal of Production Economics, 84(1), 17-34.

Lam, S. Y., Lee, V. H., Ooi, K. B., \& Lin, B. (2011). The relationship between TQM, learning orientation and market performance in service organisations: An empirical analysis. Total Quality Management \& Business Excellence, 22(12), 1277-1297.

Lam, S. Y., Lee, V. H., Ooi, K. B., \& Phusavat, K. (2012). A structural equation model of TQM, market orientation and service quality: Evidence from a developing nation. Managing Service Quality: An International Journal, 22(3), 281-309.

Lechner, C., \& Gudmundsson, S. V. (2014). Entrepreneurial orientation, firm strategy and small firm performance. International Small Business Journal, 32(1), 36-60.

Li, Y., Wei, Z., \& Liu, Y. (2010). Strategic Orientations, Knowledge Acquisition, and Firm Performance: The Perspective of the Vendor in Cross $\square$ Border Outsourcing. Journal of Management Studies, 47(8), 1457-1482.

Li, Y., Zhao, Y., Tan, J., \& Liu, Y. (2008). Moderating effects of entrepreneurial orientation on market orientation $\square$ performance linkage: Evidence from Chinese small firms*. Journal of small business management, 46(1), 113-133.

Litton, S. (2001). Total quality management-concept articulation. Available at: www. Unf. Edu/E, 8764.

Liu, Q. H., \& Wang, T. (2009, October). Market orientation and corporate performance: The mediated effect of marketing capability. In Industrial Engineering and Engineering Management, 2009. IEEEM'09. 16th International Conference on (pp. 2098-2102). IEEE.

Lumpkin, G. T., \& Dess, G. G. (1996). Clarifying the entrepreneurial orientation construct and linking it to performance. Academy of management Review, 21(1), 135-172.

MacDougall, S. L., \& Pike, R. H. (2003). Consider your options: changes to strategic value during implementation of advanced manufacturing technology. Omega, 31(1), 1-15.

Madrid-Guijarro, A., Auken, H. V., \& García-Pérez-de-Lema, D. (2007). An analysis of factors impacting performance of Spanish manufacturing firms. Journal of Small Business $\mathcal{E}$ Entrepreneurship, 20(4), 369-386.

Mahmoud, M. A. (2011). Market orientation and business performance among SMEs in Ghana. International Business Research, 4(1), 241.

Mahmud, N., \& Hilmi, M. F. (2014). TQM and Malaysian SMEs performance: The mediating roles of organization learning. Procedia-Social and Behavioural Sciences, 130, 216-225.

Meftah Abusa, F., \& Gibson, P. (2013). Experiences of TQM elements on organisational performance and future opportunities for a developing country. International Journal of Quality E Reliability Management, 30(9), 920-941.

Miller, D. (2011). Miller (1983) revisited: A reflection on EO research and some suggestions for the future. Entrepreneurship Theory and Practice, 35(5), 873-894. 
Mohammad Mosadegh Rad, A. (2006). The impact of organizational culture on the successful implementation of total quality management. The TQM Magazine, 18(6), 606-625.

Mohr-Jackson, I. (1998). Conceptualizing total quality orientation. European Journal of Marketing, 32(1/2), 13-22.

Mokhtar, S. S. M., \& Yusoff, R. Z. (2012). The Influence of Market Orientation, Strategic Quality Management on the Performances of Malaysian Manufacturing Firms.

Morris, M. H., \& Paul, G. W. (1987). The relationship between entrepreneurship and marketing in established firms. Journal of Business Venturing, 2(3), 247-259.

Narver, J. C., \& Slater, S. F. (1990). The effect of a market orientation on business profitability. The Journal of marketing, 20-35.

Obiwuru, T. C., Okwu, A. T., Akpa, V. O., \& Nwankwere, I. A. (2011). Effects of leadership style on organizational performance: A survey of selected small-scale enterprises in Ikosi-Ketu council development area of Lagos State, Nigeria. Australian Journal of Business and Management Research, 1(7), 100.

Olavarrieta, S., \& Friedmann, R. (2008). Market orientation, knowledge-related resources and firm performance. Journal of business research, 61(6), 623-630.

Pérez, V. F., \& Gutiérrez, L. (2013). External managerial networks, strategic flexibility and organisational learning: a comparative study among non-QM, ISO and TQM firms. Total Quality Management \& Business Excellence, 24(3-4), 243-258.

Phokha, A., \& Nonsrimuang, N. (2013). The effects of entrepreneurial orientation, learning orientation, market driving approach and strategic market planning capability on firm performance. Journal of International Business \& Economics, 13(3), 187-204.

Polat, I., \& Mutlu, H. M. (2012). The impacts of market orientation, entrepreneurial orientation, environmental uncertainty and internationalization speed on firm performance. European Researcher, (27), 1248-1254.

Powell, T. C. (1995). Total quality management as competitive advantage: a review and empirical study. Strategic management journal, 16(1), 15-37.

Prajogo, D. I., \& Hong, S. W. (2008). The effect of TQM on performance in R\&D environments: A perspective from South Korean firms. Tec novation, 28(12), 855-863.

Prajogo, D. I., \& Sohal, A. S. (2003). The relationship between TQM practices, quality performance, and innovation performance: An empirical examination. International journal of quality $\mathcal{E}$ reliability management, 20(8), 901-918.

Prajogo, D. I., \& Sohal, A. S. (2006). The relationship between organization strategy, total quality management (TQM), and organization performance--the mediating role of TQM. European Journal of Operational Research, 168(1), 35-50.

Raju, P. S., Lonial, S. C., \& Crum, M. D. (2011). Market orientation in the context of SMEs: A conceptual framework. Journal of Business Research, 64(12), 1320-1326.

Rauch, A., Wiklund, J., Lumpkin, G. T., \& Frese, M. (2009). Entrepreneurial orientation and business performance: An assessment of past research and suggestions for the future. Entrepreneurship theory and practice, 33(3), 761-787.

Rodrigues, R. G., \& Raposo, M. (2011). Entrepreneurial orientation, human resources information management, and firm performance in SMEs. Canadian Journal of Administrative Sciences/Revue Canadienne des Sciences de administration, 28(2), 143-153.

Sadikoglu, E., \& Zehir, C. (2010). Investigating the effects of innovation and employee performance on the relationship between total quality management practices and firm performance: An empirical study of Turkish firms. International Journal of Production Economics, 127(1), 13-26.

Samson, D., \& Terziovski, M. (1999). The relationship between total quality management practices and operational performance. Journal of operations management, 17(4), 393-409.

Schein, E. H. (1984). Coming to a new awareness of organizational culture. Sloan management review, 25(2), 3 . 
Shehu, A. M., \& Mahmood, R. (2014). An Empirical Analysis of Market Orientation and Business Performance Relationship in the Context of Developing Economy. International Journal of Academic Research in Business and Social Sciences, 4(9), 457.

Sigler, T. H., \& Pearson, C. M. (2000). Creating an empowering culture: examining the relationship between organizational culture and perceptions of empowerment. Journal of Quality Management, 5(1), 27-52.

Sila, I. (2007). Examining the effects of contextual factors on TQM and performance through the lens of organizational theories: An empirical study. Journal of Operations management, 25(1), 83-109.

Singh, P. J., \& Smith, A. J. (2004). Relationship between TQM and innovation: an empirical study. Journal of Manufacturing Technology Management, 15(5), 394-401.

Slater, S. F., \& Narver, J. C. (1998). Research notes and communications customer-led and marketoriented: Let's not confuse the two. Strategic management journal, 19(10), 1001-1006.

Slater, S. F., \& Narver, J. C. (1995). Market orientation and the learning organization. Journal of Marketing, 59(3), $63 \square 74$.

Suliyanto, S., \& Rahab, R. (2012). The role of market orientation and learning orientation in improving innovativeness and performance of small and medium enterprises. Asian Social Science, 8(1), 134.

Tajeddini, K. (2010). Effect of customer orientation and entrepreneurial orientation on innovativeness: Evidence from the hotel industry in Switzerland. Tourism Management, 31(2), 221-231.

Talib, F., Rahman, Z., \& Qureshi, M. N. (2010). The relationship between total quality management and quality performance in the service industry: a theoretical model. International Journal of Business, Management and social sciences, 1(1), 113-128.

Tan, B. I. (2013). TQM adoption and organisational performance of family owned businesses: a literature review and proposed structural model. International Journal of Modelling in Operations Management, 3(1), 1-19.

Teece, D. J. (2007). Explicating dynamic capabilities: the nature and micro foundations of (sustainable) enterprise performance. Strategic management journal, 28(13), 1319-1350.

Teixeira, H. N., Lopes, I., \& Sousa, S. (2015). Prioritizing quality problems in SMEs: a methodology. The TQM Journal, 27(1), 2-21.

Thai Hoang, D., Igel, B., \& Laosirihongthong, T. (2006). The impact of total quality management on innovation: Findings from a developing country. International journal of quality $\mathcal{E}$ reliability management, 23(9), 1092-1117.

Urban, B. (2010). Technology and entrepreneurial orientation at the organisational level in the Johannesburg area. SA Journal of Human Resource Management, 8(1), 9-pages.

Valmohammadi, C., \& Roshanzamir, S. (2015). The guidelines of improvement: Relations among organizational culture, TQM and performance. International Journal of Production Economics, 164, 167-178.

Valmohammadi, C., \& Servati, A. (2011). Performance measurement system implementation using Balanced Scorecard and statistical methods. International Journal of Productivity and Performance Management, 60(5), 493-511.

Venkatraman, N., \& Ramanujam, V. (1986). Measurement of business performance in strategy research: A comparison of approaches. Academy of management review, 11(4), 801-814.

Vieira, V. A. (2010). Antecedents and consequences of market orientation: a Brazilian meta-analysis and an international mega-analysis. BAR-Brazilian Administration Review, 7(1), 40-58.

Wales, W. J., Gupta, V. K., \& Mousa, F. T. (2011). Empirical research on entrepreneurial orientation: An assessment and suggestions for future research. International Small Business Journal, 0266242611418261.

Walter, A., Auer, M., \& Ritter, T. (2006). The impact of network capabilities and entrepreneurial orientation on university spin-off performance. Journal of business venturing, 21(4), 541-567. 
Wang, C. H., Chen, K. Y., \& Chen, S. C. (2012). Total quality management, market orientation and hotel performance: The moderating effects of external environmental factors. International Journal of Hospitality Management, 31(1), 119-129.

Wang, H. K., \& Yen, Y. F. (2012). An empirical exploration of corporate entrepreneurial orientation and performance in Taiwanese SMEs: A perspective of multidimensional construct. Total Quality Management \& Business Excellence, 23(9-10), 1035-1044.

Wanjau, K. L., Gakure, R. W., Peterson, O. M., \& Kahiri, J. (2013). The Role of quality adoption In Growth and Management of Small \& Medium Enterprises in Kenya. European Scientific Journal, 9(7).

Webb, J. W., Ireland, R. D., Hitt, M. A., Kistruck, G. M., \& Tihanyi, L. (2011). Where is the opportunity without the customer? An integration of marketing activities, the entrepreneurship process, and institutional theory. Journal of the Academy of Marketing Science, 39(4), 537-554.

Wijetunge, W. A. D. S., \& Pushpakumari, M. D. (2014). Entrepreneurial orientation and business performance of small and medium scale enterprises of Western Province in Sri Lanka. Kelaniya Journal of Management, 2(2).

Wiklund, J., \& Shepherd, D. (2003). Knowledge $\square$ based resources, entrepreneurial orientation, and the performance of small and medium $\square$ sized businesses. Strategic management journal, 24(13), 1307-1314.

Wiklund, J., \& Shepherd, D. (2005). Entrepreneurial orientation and small business performance: a configurational approach. Journal of business venturing, 20(1), 71-91.

Wiklund, J., \& Shepherd, D. A. (2011). Where to From Here? EO $\square$ as $\square$ Experimentation, Failure, and Distribution of Outcomes. Entrepreneurship Theory and Practice, 35(5), 925-946.

Wilson, G. A., Perepelkin, J., Di Zhang, D., \& Vachon, M. A. (2014). Market orientation, alliance orientation, and business performance in the biotechnology industry. Journal of Commercial Biotechnology, 20(2).

Xenikou, A., \& Simosi, M. (2006). Organizational culture and transformational leadership as predictors of business unit performance. Journal of managerial psychology, 21(6), 566-579.

Yusof, S. R. M., \& Aspinwall, E. (2000). Total quality management implementation frameworks: comparison and review. Total Quality Management, 11(3), 281-294.

Zainol, F. A., \& Ayadurai, S. (2011). Entrepreneurial orientation and firm performance: the role of personality traits in Malay family firms in Malaysia. International Journal of Business and Social Science, 2(1).

Zakuan, N. M., Yusof, S. M., \& Shaharoun, A. M. (2009, December). The link between total quality management and organizational performance in Malaysian Automotive Industry: The mediating role of ISO/TS16949 efforts. In Industrial Engineering and Engineering Management, 2009. IEEM 2009. IEEE International Conference on (pp. 439-443). IEEE.

Zehir, C., Müceldili, B., Zehir, S., \& Ertosun, Ö. G. (2012). The mediating role of firm innovativeness on management leadership and performance relationship. Procedia-Social and Behavioural Sciences, 41, 29-36.

Zelbst, P. J., Green Jr, K. W., Abshire, R. D., \& Sower, V. E. (2010). Relationships among market orientation, JIT, TQM, and agility. Industrial Management $\mathcal{E}$ Data Systems, 110(5), 637-658.

Zheng, W., Yang, B., \& McLean, G. N. (2010). Linking organizational culture, structure, strategy, and organizational effectiveness: Mediating role of knowledge management. Journal of Business research, 63(7), 763-771.

Zhou, K. Z., Li, J. J., Zhou, N., \& Su, C. (2008). Market orientation, job satisfaction, product quality, and firm performance: evidence from China. Strategic Management Journal, 29(9), 985-1000.

Zu, X., Robbins, T. L., \& Fredendall, L. D. (2010). Mapping the critical links between organizational culture and TQM/Six Sigma practices. International Journal of Production Economics, 123(1), 86106. 